\title{
BEHAVIOR OF SULFUR TRIOXIDE FORMATION IN 1.6MW PILOT PLANT FIRING HIGH SULFUR COALS INCLUDING PETROLEUM COKE BLENDS
}

\author{
Miki SHIMOGORI*, Hitoshi WAKAMATSU*, Toshihiko MINE* and Satoshi TADAKUMA* \\ * Babcock-Hitachi K.K.Kure Research Laboratory, 5-3 Takara-machi, Kure-shi, Hiroshima 737-0029, Japan
}

\begin{abstract}
To understand $\mathrm{SO}_{2}$ oxidation mechanism in boiler furnaces and to examine its factors quantitatively, the effects of coal type and combustion stoichiometry on $\mathrm{SO}_{3}$ formation have been investigated by conducting tests at $1.6 \mathrm{MWth}$ pilot plant having a test section simulating a horizontal tube bank. $\mathrm{SO}_{3}$ concentration was high for coals containing high amounts of sulfur and vanadium oxides. $\mathrm{SO}_{3}$ concentration decreased linearly with decreasing $\mathrm{O}_{2}$ concentration. Reduction of combustion stoichiometry from 1.5 to 1.2 decreased $\mathrm{SO}_{2}$ oxidation rate from 1.4 to $0.6 \%$ and from 2.4 to $1.0 \%$ for high sulfur coal and $40 \%$ petroleum coke blend, respectively. Our results are consistent with some field data and also significant for quantifying the effects of operating conditions on reducing $\mathrm{SO}_{3}$.
\end{abstract}

Keywords: $\mathrm{SO}_{3}$ formation, High sulfur coals, Petroleum coke, Combustion stoichiometry, Pilot plant test

\section{INTRODUCTION}

Excessive level of $\mathrm{SO}_{3}$ emission from high sulfur coal-fired boilers is problematic because of increasing corrosion rate of down stream surfaces and plume opacity at the stack. During coal combustion, sulfur in coal is converted to $\mathrm{SO}_{2}$ in the furnace, and 1 to $3 \%$ of $\mathrm{SO}_{2}$ further oxidizes to $\mathrm{SO}_{3}$ at the convection pass and Selective catalytic reduction (SCR) system [1]. To mitigate $\mathrm{SO}_{3}$ emission, factors essential for its formation and depletion should be understood quantitatively. Previous research has revealed that factors influencing the amount of $\mathrm{SO}_{3}$ generated in furnaces are coal types, boiler types and operating conditions [2][3][4]. However, $\mathrm{SO}_{2}$ oxidation data from actual combustion fields is still lacking to evaluate the degree of incidence among the factors.

The purpose of our work is to understand the $\mathrm{SO}_{2}$ oxidation mechanism in actual combustion fields, and to evaluate the factors affecting $\mathrm{SO}_{3}$ emission quantitatively. For this purpose, we have conducted tests at 1.6MWth pilot plant having a test section simulating a horizontal tube bank. This paper discusses the effect of coal type and combustion stoichiometry on $\mathrm{SO}_{3}$ formation based on data obtained by the pilot plant tests.

\section{EXPERIMENTAL}

\subsection{6MW Pilot Plant}

Fig.1 shows the appearance and the schematics of the pilot plant operated for a series of tests. The combustor is a down flow furnace with a burner installed on the top. Furnace exhaust gas is cooled by an air heater and is introduced to an Air Quality Control System (AQCS) test facility, which consisted of an SCR, a gas-gas heater (GGH), a dry electrostatic precipitator (ESP), and FGD system. To investigate the effect of deposit ash on $\mathrm{SO}_{3}$ formation, we installed a test section simulating a boiler tube bank upstream of the air heater. Gas temperature at the test section inlet was $923 \mathrm{~K}$ and decreased to $823 \mathrm{~K}$ at the test section outlet. Gas flow rate in the section was $13 \mathrm{~m} / \mathrm{s}$, and the residence time in the section was 0.1 second. In practical boilers, gas flow rate ranges from 10 to $30 \mathrm{~m} / \mathrm{s}$. The residence time of 0.1 second in pilot plant corresponds to that of one bank installed in a 1000MW-class boiler.

$\mathrm{SO}_{3}$ measurement ports with diameter of $40 \mathrm{~mm}$ were located in position (a), (b), (c) and (d). Ports (c) and (d) were placed on the gas ducts upstream and downstream the test section to investigate the $\mathrm{SO}_{3}$ formation at the simulating bank area.

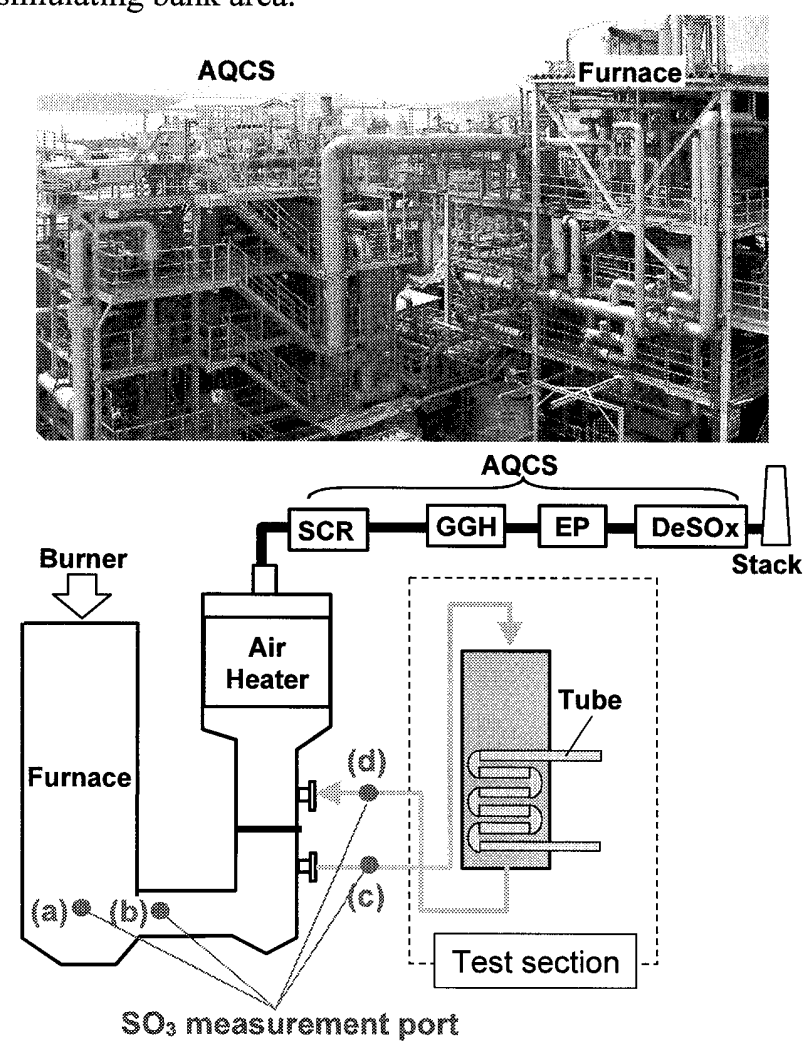

Fig.1 Appearance and schematics of the pilot plant operated for a series of tests 
Table1 lists the main test conditions of each test runs. We selected 2 types of U.S. eastern coals, which are Coals $\mathrm{A}$ and $\mathrm{B}$, and prepared petroleum coke blends with the blend ratio of 20 and $40 \%$ by mixing petroleum coke and Coal $\mathrm{B}$ on a weight bases. For simplicity, in tables and figures in this paper, we represented 20 and $40 \%$ petroleum coke blends in pet coke $20 \%$ and pet coke $40 \%$, respectively. Each test run has been performed for 4 or 5 days with the coal feed rate in range from 60 to $70 \mathrm{~kg} / \mathrm{h}$. The effect of stoichiometry was evaluated with the tests using Coal B itself and a $40 \%$ petroleum coke blend.

Table 1 Main test conditions for 1.6MW Pilot Plant tests

\begin{tabular}{|c|c|c|c|c|}
\hline Coal & Coal A & Coal B & $\begin{array}{c}\text { Pet coke } \\
20 \%\end{array}$ & $\begin{array}{c}\text { Pet coke } \\
40 \%\end{array}$ \\
\hline Item Test time [h] & 70 & 77 & 74 & 72 \\
\hline Coal feed rate [kg/h] & 60 & 70 & 65 & 60 \\
\hline Total stoichiometry [-] & 1.5 & $1.2-1.5$ & 1.5 & $1.2-1.5$ \\
\hline $\begin{array}{c}\text { Gas temperature at the } \\
\text { test section inlet [K] }\end{array}$ & \multicolumn{4}{|c|}{$823-923$} \\
\hline $\begin{array}{c}\text { Temperature of cooling } \\
\text { air of the bank [K] }\end{array}$ & \multicolumn{4}{|c|}{ Inlet:313, Outlet:623 } \\
\hline
\end{tabular}

\subsection{Test Section Simulating Horizontal Tube Bank}

Fig. 2 shows the schematics of the test section. An engineering drawing of the tube bank is shown in Fig.3. The bank size was reduced to $1 / 1000$ scale of actual ones with satisfaction of geometric similarity. A bare tube having a diameter of $57 \mathrm{~mm}$ constructed the bank, and was arranged 3 rows in width direction and 14rows in gas flow direction. Combustion gas was introduced from the topside to the bottom side of the test section. Cooling air was supplied from the bottom header of the bank at the temperature of $313 \mathrm{~K}$ and discharged to the atmosphere through the upper header at the temperature of $623 \mathrm{~K}$. Temperature of cooling air was measured at 5 locations with the attached K-type thermocouples of $0.1 \mathrm{~mm}$ diameter. The flow rate of cooling air was measured by an orifice flow meter mounted at the inlet of the airflow. Data from thermocouples and the flow meter were recorded with a data logger in the control room of the test plant.

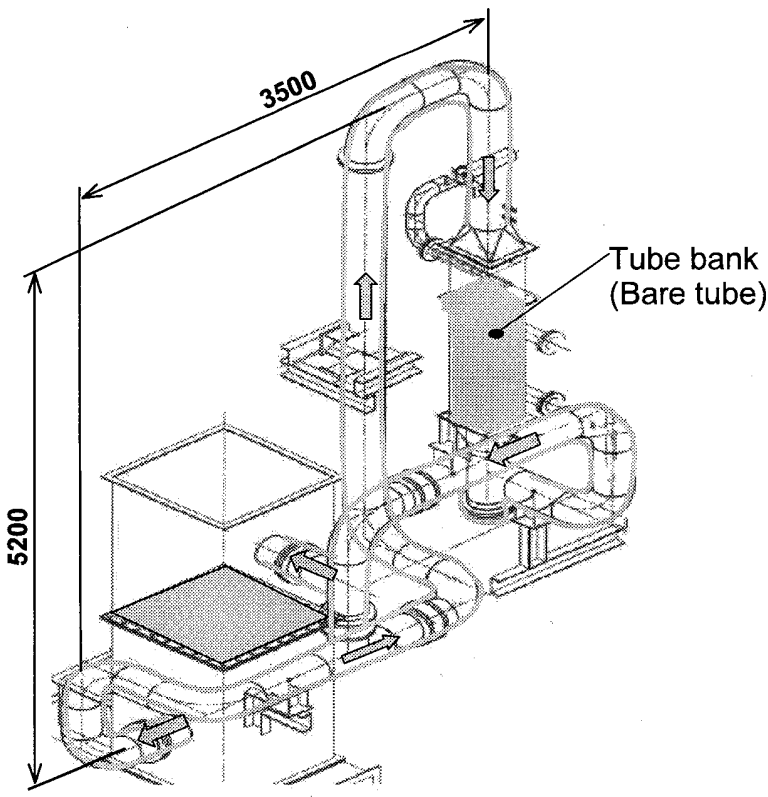

Fig. 2 schematics of the test section

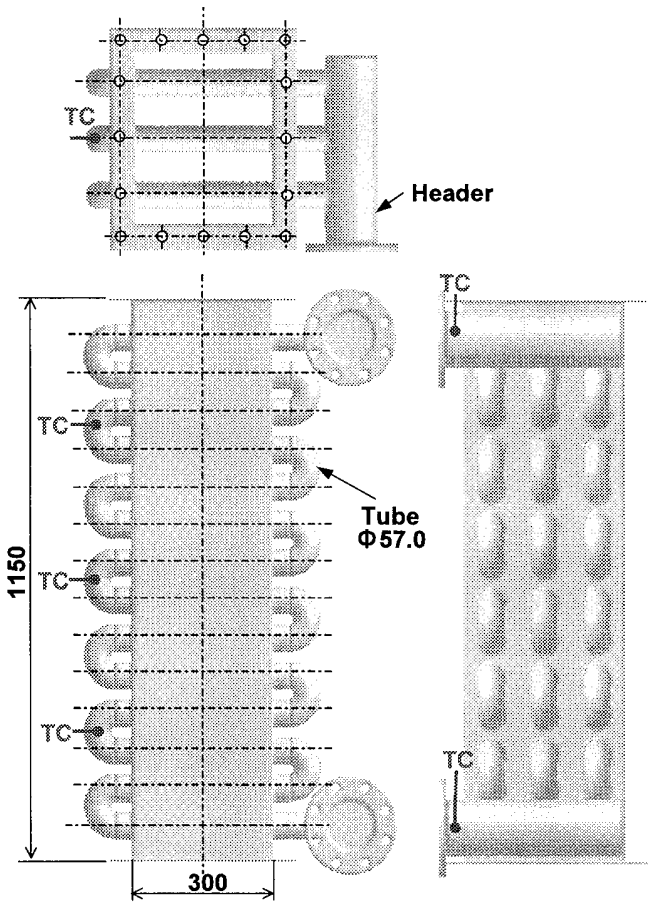

Fig.3 Engineering drawing of the tube bank

\subsection{Coal and Ash Analysis}

The results of coal and ash analysis are listed in Table 2. Sulfur in coal varies from 1.6 to $3.5 \%$ and ash contents range from 6.1 to $10.3 \%$. The amount of iron oxides in ash of tested coal was from 14 to $18 \%$ and this variation was not sufficient to distinguish each other. On the other hand, the amount of vanadium oxides was distinctive for each coal; it increased with increasing blend ratio of petroleum coke to Coal B. For example, the amounts of vanadium oxides were $0.09,0.32$, and $0.98 \%$ for the coals with Coal B itself, $20 \%$ and $40 \%$ petroleum coke blends, respectively.

As Graham et al have addressed in their study [5], iron oxides are well known catalysts for $\mathrm{SO}_{2}$ oxidation. However, we do not use coals containing low iron oxides, such as Powder River Basin coals, because of low $\mathrm{SO}_{3}$ emission. We decided that it is not appropriate to discuss the effect of test parameters with the small amount of $\mathrm{SO}_{3}$.

Table2 Properties of coal and ash used pilot test

\begin{tabular}{|c|c|c|c|c|c|}
\hline \multicolumn{6}{|c|}{ Coal Analysis } \\
\hline Item & Unit & Coal A & Coal B & Petcoke20\% & Petcoke40\% \\
\hline $\mathrm{HHV}$ & $\mathrm{kJ} / \mathrm{kg}$ & 28180 & 27160 & 28330 & 30860 \\
\hline $\begin{array}{c}\text { Total } \\
\text { moisture }\end{array}$ & wt\% & 7.8 & 13.7 & 14.2 & 7.0 \\
\hline Ash & $w t \%$ & 8.2 & 10.3 & 10.2 & 6.1 \\
\hline $\mathrm{C}$ & wt\% & 72.9 & 71.1 & 72.4 & 77.4 \\
\hline $\mathrm{H}$ & $w t \%$ & 4.6 & 4.7 & 4.3 & 4.1 \\
\hline $\mathrm{O}$ & $w t \%$ & 11.1 & 10.0 & 8.7 & 6.3 \\
\hline $\mathrm{N}$ & $w t \%$ & 1.6 & 1.6 & 1.6 & 1.8 \\
\hline $\mathrm{S}$ & wt\% & 1.6 & 2.7 & 3.0 & 3.5 \\
\hline Fuel ratio & - & 1.8 & 1.7 & 1.7 & 2.5 \\
\hline \multicolumn{7}{|c|}{ Ash Analysis } \\
\hline $\mathrm{Fe}_{2} \mathrm{O}_{3}$ & wt\% & 18.2 & 17.1 & 14.1 & 16.5 \\
\hline $\mathrm{V}_{2} \mathrm{O}_{5}$ & wt\% & 0.09 & 0.09 & 0.32 & 0.98 \\
\hline
\end{tabular}

\subsection{Measurement of $\mathrm{SO}_{3}$ Concentration}

As illustrated in Fig.1, $\mathrm{SO}_{3}$ concentrations were measured at (a) furnace hopper, (b) horizontal duct, (c) test section inlet, and (d) test section outlet. To quantify 
reproducibility and errors in $\mathrm{SO}_{3}$ values, measurements were repeated 2 or 3 times for each test condition. At each measurement, $\mathrm{SO}_{3}$ sampling nozzle was inserted in the center of each duct or pipe to minimize the effect of distribution of $\mathrm{SO}_{3}$ concentration in each flow passage plane. Sample gas was extracted through a quartz fiber filter inserted in the duct then passed through a spiral glass tube condenser. Temperature of the condenser was controlled at $373 \mathrm{~K}$. After each sampling, the filter and the condenser were rinsed with purified water separately. Then SO4- concentration in each wash solution was analyzed by ion chromatography. The measurement limit of $\mathrm{SO}_{3}$ was less than $0.1 \mathrm{ppm}$.

$\mathrm{SO}_{3}$ captured on the filter is assumed to be formed during combustion and originally existed in gaseous phase. Therefore, we added filtered and condensed $\mathrm{SO}_{3}$ for data evaluation. Obtained $\mathrm{SO}_{3}$ values were represented based on $6 \%$ of excess $\mathrm{O}_{2}$.

\section{RESULTS}

\subsection{Effect of Coal Type}

Table 3 summarizes $\mathrm{SO}_{3}$ concentrations measured at the test section outlet; hereinafter called $\mathrm{SO}_{3 \text { outlet }}$, for each tested coal with theoretical $\mathrm{SO}_{2}$ concentrations and $\mathrm{SO}_{2}$ oxidation rates. Theoretical $\mathrm{SO}_{2}$ concentrations were calculated based on Sulfur in each coal. $\mathrm{SO}_{2}$ oxidation rates were obtained by dividing $\mathrm{SO}_{3 \text { outlet }}$ by theoretical $\mathrm{SO}_{2}$.

Table 3 Comparison of $\mathrm{SO}_{3 \text { outlet }}$ for different types of coal

\begin{tabular}{|c|c|c|c|c|c|}
\hline Item & Unit & Coal A & Coal B & $\begin{array}{c}\text { Pet coke } \\
20 \%\end{array}$ & $\begin{array}{c}\text { Pet coke } \\
40 \%\end{array}$ \\
\hline $\mathrm{S}$ & $\mathrm{wt} \%$ & 1.6 & 2.7 & 3.0 & 3.5 \\
\hline $\mathrm{V}_{2} \mathrm{O}_{5}$ & $\mathrm{wt} \%$ & 0.09 & 0.09 & 0.32 & 0.98 \\
\hline $\mathrm{SO}_{3}$ & $\mathrm{ppm}, 6 \% \mathrm{O}_{2}$ & 8 & 23 & 58 & 64 \\
\hline $\mathrm{SO}_{2}$ & $\mathrm{ppm}, 6 \% \mathrm{O}_{2}$ & 1131 & 1903 & 2080 & 2246 \\
\hline $\begin{array}{c}\mathrm{SO}_{2} \\
\text { oxidation } \\
\text { rate }\end{array}$ & $\mathrm{wt} \%$ & 0.6 & 1.2 & 2.8 & 2.8 \\
\hline
\end{tabular}

$\mathrm{SO}_{3 \text { outlet }}$ were $8,23,58$, and $64 \mathrm{ppm}$, which increased in the following order: Coal A, Coal B, $20 \%$ and $40 \%$ petroleum coke blends. The results in Fig. 3 indicate that $\mathrm{SO}_{3 \text { outlet }}$ was higher for the coal containing higher amounts of sulfur and vanadium oxides.

In our tests, the $\mathrm{SO}_{2}$ oxidation rate was 0.6 and $1.2 \%$ for high sulfur coals, and $2.8 \%$ for petroleum coke blends.

Referring to some field data in papers [1][2], $\mathrm{SO}_{2}$ oxidation rates at the economizer of practical boilers are from 0.9 to $1.7 \%$ for high sulfur coals and 1.7 to $3.3 \%$ for petroleum coke blends. Our test data were in the reasonable range of those field data.

\section{2 $\mathrm{SO}_{3}$ Formation in Furnace}

To understand the mechanism of $\mathrm{SO}_{3}$ formation during the combustion process, the trends in $\mathrm{SO}_{3}$ concentration as increased residence time were compared for Coal A, Coal B and 20\% petroleum coke blend in Fig.4. For all coals, most $\mathrm{SO}_{3}$ were formed at the area where the gas temperature above $1073 \mathrm{~K}$. At the area where the gas cooled below $1073 \mathrm{~K}$, the trend of $\mathrm{SO}_{3}$ formation differed whether the tested coal contains petroleum coke or does not.
More specifically, the amount of $\mathrm{SO}_{3}$ decreased for Coal A and Coal B, whereas it increased for $20 \%$ petroleum coke blend as increased residence time.

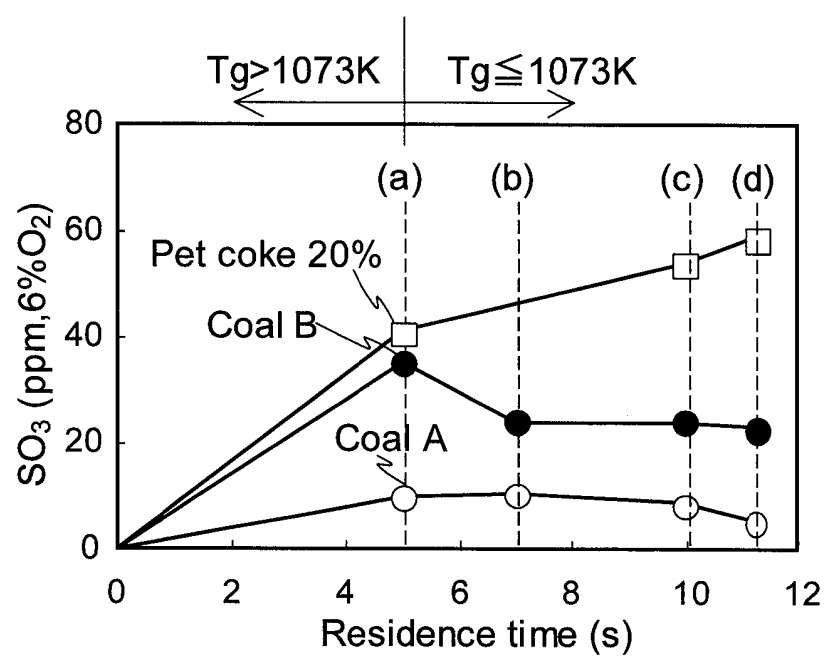

Fig.4 Trend of $\mathrm{SO}_{3}$ formation as a function of residence time from burner exit

$\mathrm{SO}_{3}$ formation in the test section was evaluated by plotting measured $\mathrm{SO}_{3}$ at the section inlet; hereafter called $\mathrm{SO}_{3 \text { inlet, }}$ versus $\mathrm{SO}_{3 \text { outlet }}$ (see Figs. 5 to 8 ). We measured $\mathrm{SO}_{3}$ three times for each measurement condition to quantify reproducibility. Plots in figures represent values based on average $\mathrm{SO}_{3}$ values of three measurements performed at the test section inlet and the outlet, and each plot area was illustrated as grey in all figures.

As a general trend, all plots in Figs. 5 to 8 scattered along the reference lines showing one to one relation between $\mathrm{SO}_{3 \text { inlet }}$ and $\mathrm{SO}_{3 \text { outlet }}$. Thus the difference between them was relatively small.

However, when we focus on the exact positions of the plot areas (grey areas) against the reference lines, there can be seen some specific features derived from coal type. For example, the plots of Coal A tended to sift lower side against the reference line (in Fig. 5), on the other hands, the plots of Coal B and 20\% petroleum coke blend (in Figs. 6 and 7) tended to shift upper side against the line. The plots of $40 \%$ petroleum coke blend (in Fig. 8), distributed across the reference line.

According to these diagnostics, the following can be understood: (1) $\mathrm{SO}_{3 \text { outlet }}$ tends to be lower than the inlet $\mathrm{SO}_{3}$ for Coal $\mathrm{A}$ and to be higher for Coal $\mathrm{B}$ and $20 \%$ petroleum coke blend, and (2) $\mathrm{SO}_{3 \text { inlet }}$ and $\mathrm{SO}_{3 \text { outlet }}$ are almost equal for $40 \%$ petroleum. 


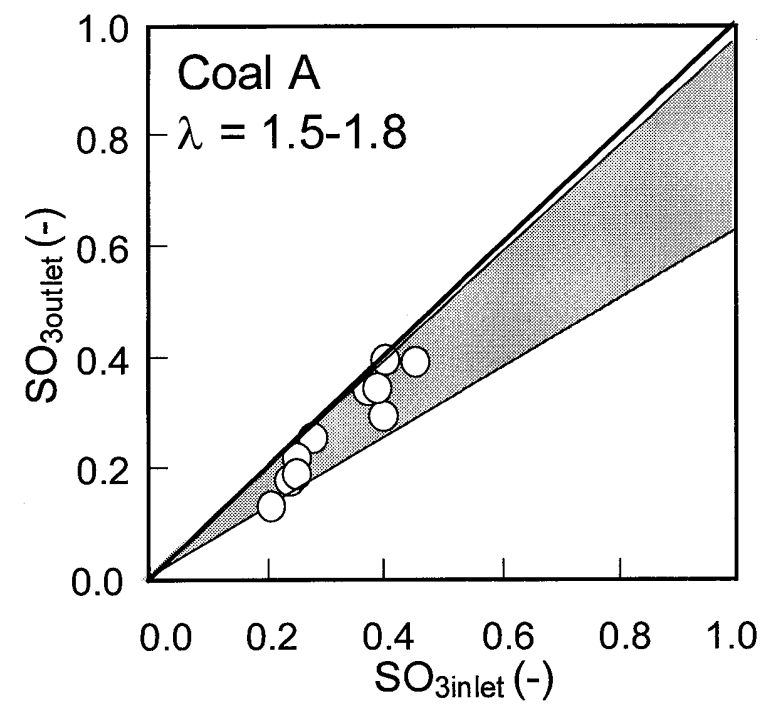

Fig. 5 Plots of $\mathrm{SO}_{3}$ measured at the inlet and outlet of the test section at Coal A tests

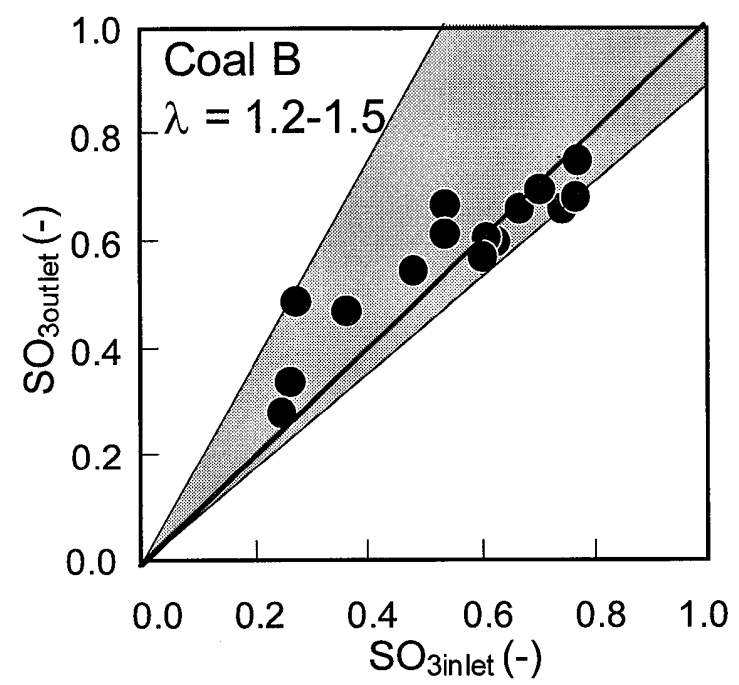

Fig. 6 Plots of $\mathrm{SO}_{3}$ measured at the inlet and outlet of the test section at Coal B tests

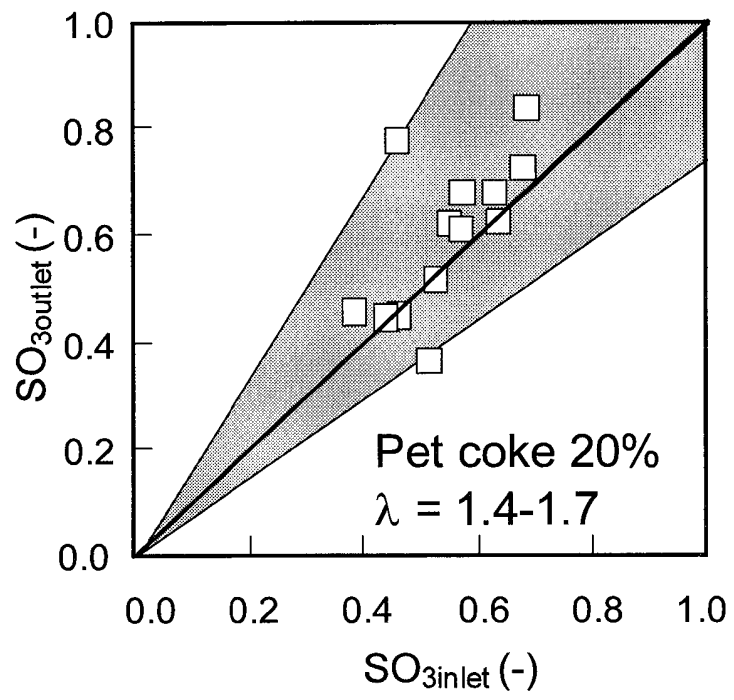

Fig. 7 Plots of $\mathrm{SO}_{3}$ measured at the inlet and outlet of the test section at $20 \%$ Petroleum coke blend tests

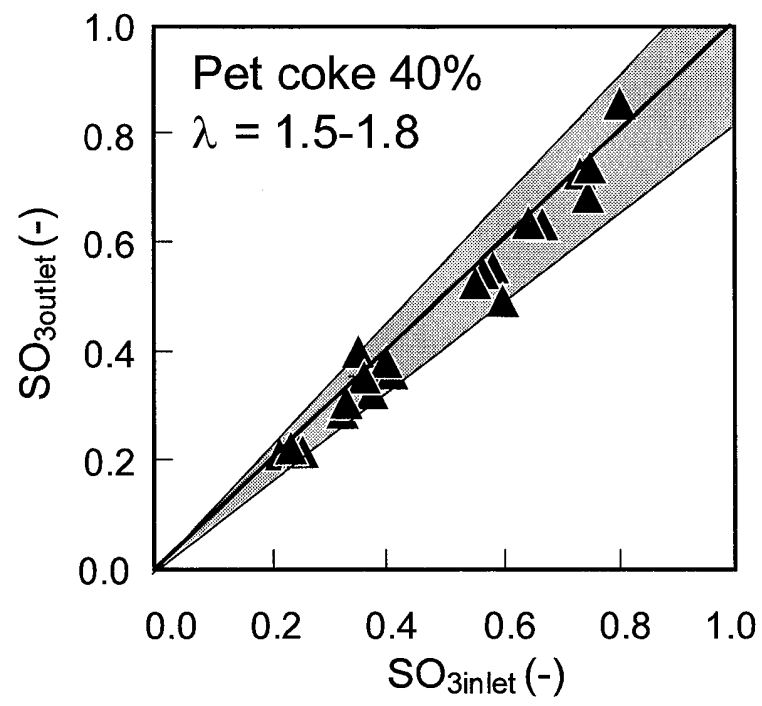

Fig. 8 Plots of $\mathrm{SO}_{3}$ measured at the inlet and outlet of the test section at $40 \%$ Petroleum coke blend tests

\subsection{Effect of Combustion Stoichiometry}

We investigated the effect of combustion stoichiometry on $\mathrm{SO}_{3}$ formation at the tests of Coal $\mathrm{B}$ and $40 \%$ petroleum coke blend coals. For these tests, we varied stoichiometry from 1.2 to 1.5 based on the field data of economizer $\mathrm{O}_{2}(=3-6 \%)$ of practical boilers in U.S. As is shown in Fig.9, $\mathrm{SO}_{3}$ concentration decreases almost linearly with decreasing $\mathrm{O}_{2}$ concentration for both coals, and the difference between $\mathrm{SO}_{3}$ concentrations at the same $\mathrm{O}_{2}$ concentration became smaller at lower $\mathrm{O}_{2}$ concentration.

The relationships between combustion stoichiometry and $\mathrm{SO}_{2}$ oxidation of each coal are shown in Figs. 10 and 11 . $\mathrm{By}$ reducing combustion stoichiometry from 1.5 to $1.2, \mathrm{SO}_{2}$ oxidation rates decreased from 1.4 to $0.6 \%$ for Coal $\mathrm{B}$ and from 2.4 to $1.0 \%$ for $40 \%$ petroleum coke blend. Maximum variations in data against the correlation lines were $30 \%$ for Coal B and $40 \%$ for $40 \%$ petroleum coke blend (grey areas shown in Figs. 10 and 11).

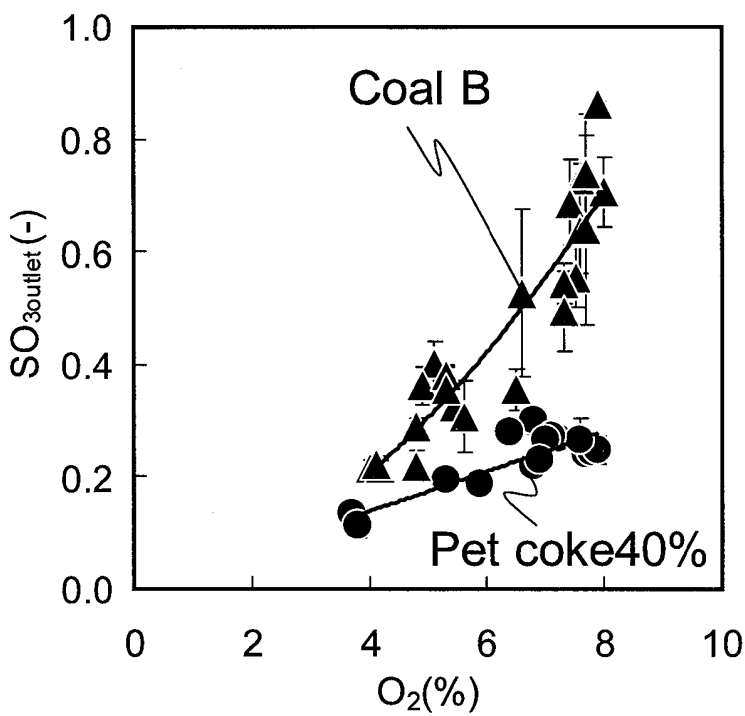

Fig. 9 Variation of $\mathrm{SO}_{3}$ at the test section outlet with $\mathrm{O}_{2}$ at the furnace exit for different types of coal 


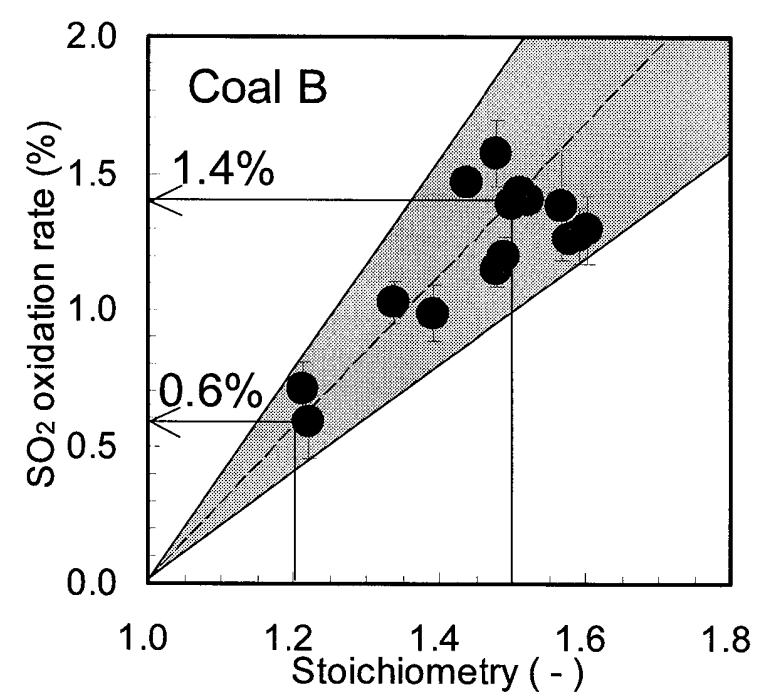

Fig.10 Variation of $\mathrm{SO}_{2}$ oxidation rate with stoichiometry at the Coal B test

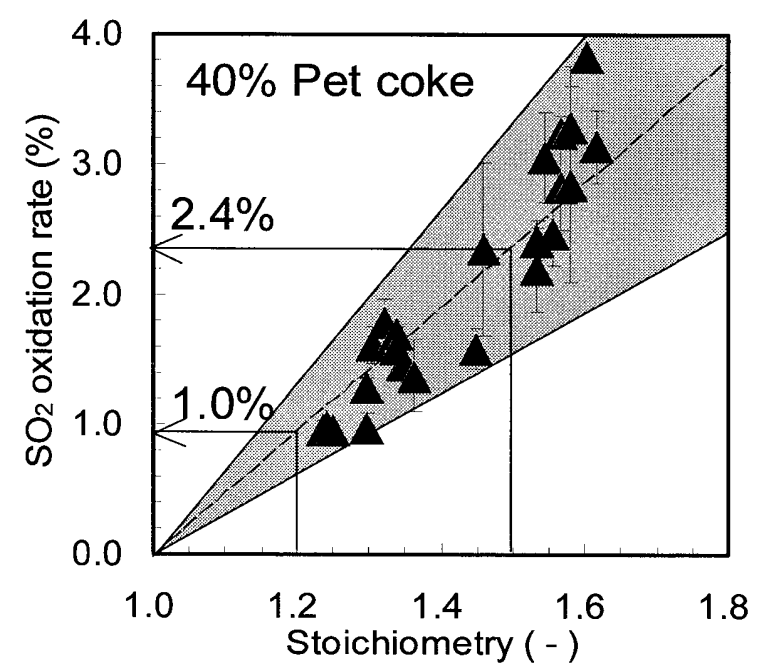

Fig. 11 Variation of $\mathrm{SO}_{2}$ oxidation rate with stoichiometry at the $40 \%$ Petroleum coke blend tests

\section{DISCUSSION}

To understand the formation mechanism of $\mathrm{SO}_{3}$ in boiler furnaces and to examine the factors quantitatively, a series of tests have been conducted at $1.6 \mathrm{MW}$ th pilot plant having a test section simulating a horizontal tube bank. The effects of coal type and combustion stoichiometry on $\mathrm{SO}_{3}$ formation are discussed below.

$\mathrm{SO}_{3}$ concentration was higher for the coal containing higher amounts of sulfur and vanadium oxides. When sulfur in coal burns in furnace, most of them are converted to $\mathrm{SO}_{2}$, and then further oxidized to $\mathrm{SO}_{3}$ with a certain oxidation rate. Hence, under the same oxidation rate, coals containing higher amount of sulfur inevitably produces higher $\mathrm{SO}_{3}$. Also, vanadium oxides in petroleum coke are well-known catalyst of $\mathrm{SO}_{2}$ oxidation and accelerate the oxidation reaction. In addition, $\mathrm{SO}_{2}$ oxidation rates of our test results were found to be in reasonable range of field data from U.S. power plants (see, for example, [2]). This consistency helps to ensure the validity of our pilot plant tests on examining $\mathrm{SO}_{2}$ oxidation characteristics in boiler furnaces.

The trend of $\mathrm{SO}_{3}$ formation at the area where gas temperature below $1073 \mathrm{~K}$ differed whether the tested coal contains petroleum coke or does not. For Coals A and B, the amount of $\mathrm{SO}_{3}$ decreased with increasing residence time. As the reason for this, it assumed that the accumulated ash in the horizontal duct captured $\mathrm{SO}_{3}$. In this case, $\mathrm{SO}_{3}$ stays in the furnace and are not to be measured. In contrast, the amount of $\mathrm{SO}_{3}$ increased for $20 \%$ petroleum coke blend. This believed to be due to catalytic effect of vanadium oxides in petroleum coke. From these effects, ash deposition behavior is also supposed to affect the difference in $\mathrm{SO}_{3}$ concentration for each coal. However, the difference between ash deposition behaviors of tested coals, specifically the amount of accumulated ash in the horizontal duct and deposited ash on tubes in the test section, was not pronounced.

$\mathrm{SO}_{3}$ formation in the test section simulating a boiler tube bank was difficult to evaluate because the difference between $\mathrm{SO}_{3}$ measured at the test section inlet and that at the outlet was relatively small. The reason for this is probably due to the short residence time; 0.1 second, in the test section. As shown in Fig.1, the residence time from the burner exit to the test section inlet was 10 seconds and most $\mathrm{SO}_{3}$ were formed before the test section inlet. In experiments, there is a limitation of increasing residence time because of their facility scale.

Some small specific features derived from coal type can be explained by the balance between the adsorption effect of unburned carbon in ash (UBC) and the catalytic effect of iron and vanadium oxides. UBC of Coal A, in

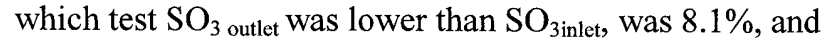
was the highest amount among those of other coals (Coal B; $3.3 \%, 20 \%$ petroleum coal blend; $4.5 \%, 40 \%$ petroleum coke blend; $5.7 \%$ ). From this result, $\mathrm{SO}_{3}$ was assumed to adsorb to UBC rich ash in the test section and decrease at the section outlet for Coal A; this means the adsorption effect appears to be greater than the catalytic effect. When we consider the other cases similarly, the following can be understood. In case of Coal B and $20 \%$ petroleum blend, the catalytic effect was greater than the absorption effect, and then $\mathrm{SO}_{3}$ tended to increase in the test section. In case of $40 \%$ petroleum blend, both effects are competitive (remember that UBC in ash $40 \%$ petroleum coke was $5.7 \%$, this was higher than those of Coal $\mathrm{B}$ and $20 \%$ petroleum blend), and then $\mathrm{SO}_{3}$ did not change before and after the test section.

$\mathrm{SO}_{3}$ concentration decreases almost linearly with decreasing $\mathrm{O}_{2}$ concentration for both coals. Fernando et al [2] have reported that $\mathrm{SO}_{3}$ concentration at economizer declines almost linearly at a 585MW boiler field test. Our results are consistent with their findings and also significant for quantifying the effect of combustion stoichiometry on reducing $\mathrm{SO}_{3}$.

\section{CONCLUSION}

The effects of coal type and combustion stoichiometry on $\mathrm{SO}_{3}$ formation have been investigated quantitatively by conducting tests at $1.6 \mathrm{MW}$ th pilot plant having a test section simulating horizontal tube bank.

Our study led to the following conclusions:

(a) $\mathrm{SO}_{3}$ formation was high for coals containing high amounts of sulfur and vanadium oxide.

(b) $\mathrm{SO}_{3}$ concentration decreased linearly with decreasing $\mathrm{O}_{2}$ concentration. Reduction of combustion stoichiometry from 1.5 to 1.2 decreased $\mathrm{SO}_{2}$ oxidation rate from 1.4 to $0.6 \%$ 
and from 2.4 to $1.0 \%$ for Coal B and $40 \%$ of petroleum coke blending, respectively.

(c) The amount of $\mathrm{SO}_{3}$ formed at the simulating a tube bank was relatively small compared with that at the area before the bank. There seems to be some difference in results between coals, however it is not enough to discuss the effect of coal types.

\section{REFERENCES}

1. Srivastava, R.K., Miller, C.A., Erickson, C. and Jambhekar, R., Emissions of Sulfur Trioxides from Coal-Fired Power Plants, Pro. of Power-Gen International 2002,(2002), pp.1-19.

2. Fernando, R., $\mathrm{SO}_{3}$ issues for coal-fired plant, September 2003, IEA Clean Coal Centre, ISBN92-9029-387-X

3. Levy, E.K., Romeo, C. E., Stenger, H., Yao, ZZ., Bilirgen, H., Caram, H., Modeling of SO3 formation in Coal-Fired Boilers, Pro. of Int. Conf. on Air Quality IV, (2007)

4. Walsh, P.M., McCain, J.D., and Cushing, K.M., Evaluation and Mitigation of Visible Acidic Aerosol Plume from Coal Fired Power Boilers, Final Report, EPA/600/R-06/156, September, (2006)

5. Graham, K.A., Sarofim, A.F., Inorganic Aerosols and Their Role in Catalyzing Sulfuric Acid Production in Furnaces, Air\&Waste Manage, Assoc. 48:106-112 